\title{
Clay Mineralogy, Organic Carbon Burial, and Redox Evolution in Proterozoic Oceans
}

\section{Citation}

Tosca, Nicholas J., David T. Johnston, Alexandra Arcadievna Mushegian, Daniel H. Rothman, Roger E. Summons, and Andrew Herbert Knoll. 2010. Clay mineralogy, organic carbon burial, and redox evolution in Proterozoic oceans. Geochimica et Cosmochimica Acta 74(5): 1579-1592.

\section{Published Version}

doi:10.1016/j.gca.2009.12.001

\section{Permanent link}

http://nrs.harvard.edu/urn-3:HUL.InstRepos:3934551

\section{Terms of Use}

This article was downloaded from Harvard University's DASH repository, and is made available under the terms and conditions applicable to Open Access Policy Articles, as set forth at http:// nrs.harvard.edu/urn-3:HUL.InstRepos:dash.current.terms-of-use\#OAP

\section{Share Your Story}

The Harvard community has made this article openly available.

Please share how this access benefits you. Submit a story.

\section{Accessibility}




\title{
Clay Mineralogy, Organic Carbon Burial, and Redox Evolution in
} Proterozoic Oceans

\author{
Nicholas J. Tosca1, David T. Johnston ${ }^{1}$, Alexandra Mushegian"1 , Daniel H. Rothman², \\ Roger E. Summons ${ }^{2}$, Andrew H. Knoll ${ }^{1}$ \\ ${ }^{1}$ Department of Organismic \& Evolutionary Biology, Harvard University, 26 Oxford St., \\ Cambridge, MA 02138 \\ ${ }^{2}$ Department of Earth, Atmospheric, and Planetary Sciences, Massachusetts Institute of \\ Technology, Cambridge, MA 02139
}

the burial of organic matter (OM), but because diagenesis and metamorphism commonly obscure the signature of weathering-derived clays in Precambrian rocks, clay mineralogy and its role in OM burial through much of geologic time remains incompletely understood. Here we have analyzed the mineralogy, geochemistry and total organic carbon (TOC) of organic rich shales deposited in late Archean to early Cambrian sedimentary basins. Across all samples, the predominance of $1 M$ and $1 M_{d}$ illite polytypes indicates the diagenetic transformation of smectitic clay and/or Al-rich weathering products. In late Neoproterozoic basins, however, igneous/detrital $2 M_{1}$ illite (including muscovite) dominates clay mineralogy. Correcting for K-metasomatism, paleo-weathering indices indicate that late Archean and Mesoproterozoic samples were moderately to intensely weathered. By contrast, paleo-weathering indices sharply decrease in late Neoproterozoic samples, consistent with an influx of chemically immature sediments that resulted in a predominance of micaceous clays in sampled basins. For all samples, plots of TOC vs. paleo-weathering index suggest that weathered sediments with abundant smectitic clays were the most effective in OM sequestration. Additionally, our samples show a positive 
correlation between TOC and illite crystallinity (independent of post-depositional thermal

31 effects). A late Neoproterozoic switch to detrital/igneous clays is inconsistent with

32 hypotheses for oxygen history that require an increased flux of weathering-derived clays

33 across the Precambrian-Cambrian boundary. It is, however, consistent with the empirical

measurements on which such hypotheses are based. Although late Neoproterozoic increases

35 in micaceous clay and chemically immature sediment could physically shield buried OM

36 from enzymatic breakdown, modal clay mineralogy cannot by itself explain an Ediacaran

37 increase in atmospheric oxygen driven by enhanced OM burial.

Keywords: organic carbon, Proterozoic, oxygen, clay, mineralogy, sedimentary geochemistry

\section{Introduction}

The rise of atmospheric oxygen during the last 2400 Ma (Ma: million years) of Earth

43 history has driven profound and irreversible changes, including the oxidation of the world's

44 oceans, eukaryotic diversification, and the emergence of animal life (Cloud, 1976; Holland, 1984;

45 Canfield, 2005; Gaidos et al., 2007). Atmospheric $\mathrm{O}_{2}$ accumulation can be driven by the burial

46 of OM (Des Marais et al., 1992; Catling and Claire, 2005), and because of their unique physico-

47 chemical properties, clay minerals -- in particular, smectites derived from chemical weathering --

48 have been implicated in OM sequestration. For this reason, clay mineral studies are central to

49 understanding $\mathrm{OM}$ burial and $\mathrm{O}_{2}$ accumulation through time (e.g., Kennedy et al., 2002).

50 Surprisingly, however, relatively little is known on the nature of clay mineralogy and the

51 mechanisms behind clay-TOC interactions through much of the Precambrian, when the most

52 crucial steps in Earth’s oxygenation took place (Weaver, 1989; Kennedy et al., 2006). 
Mineralogical analyses of a large number of shales by Weaver (1967; 1989) indicated

54 that smectite minerals are absent from Precambrian clay assemblages, but abundant in late

55 Paleozoic samples. Weaver (1967; 1989) suggested that either smectitic weathering products

56 were converted to more stable illite during burial diagenesis, or much of the illite is, itself, a

57 primary precipitate formed under distinctly Proterozoic environmental conditions. Based on

58 analyses of Neoproterozoic and Cambrian shales, Kennedy et al. (2006) proposed an alternative

59 hypothesis: the absence of smectite in Proterozoic shales and its appearance near the Proterozoic-

60 Cambrian boundary reflects fundamental changes in continental weathering associated with the

61 early evolution of land plants. In this view, plant-driven increases in chemical weathering and

62 clay formation led to increases in OM burial, driving late Neoproterozoic $\mathrm{O}_{2}$ increase.

63 To test this model and, more generally, to constrain better the evolution of clay

64 mineralogy through time, we examine the quantitative relationship between clays and OM from

65 the late Archean Eon to the early Cambrian Period. By sampling a range of high TOC

66 Proterozoic shales, we ask whether weathering style and magnitude of clay generation changed

67 fundamentally through the Proterozoic and how these results relate, if at all, to changes in the

68 carbon cycle and Neoproterozoic rise of atmospheric $\mathrm{O}_{2}$.

\section{2. Sample set and methods}

71 The sample set discussed here includes late Archean (2600-2500 Ma) samples from the

72 Transvaal Supergroup, South Africa, and the Mt. McRae Shale, Australia. Paleo- and

73 Mesoproterozoic shales were sampled from the McArthur Group; the Nathan Group, and the

74 Roper Group, all in northern Australia. Neoproterozoic samples come from the Chuar Group

75 (Arizona, USA; ca. $750 \mathrm{Ma}$ ) and the Ediacaran Vychegda Formation (Russia), Huqf Supergroup 
76 (Oman), Nama Group (Namibia), Polarisbreen Group (Svalbard), and the Redkino and Kotlin

77 horizons (northern Russia). Lower Cambrian samples come from the Tokammane Formation,

78 Svalbard. Details of age and location for each sample are listed in Table 1. All samples represent

79 siliciclastic shales, siltstones and mudrocks deposited in environments ranging from inner

80 shelf/shoreface to outer shelf and basinal settings. Importantly, nearly all samples have

81 experienced low to moderate thermal metamorphism despite their age (see Table 1), with the

82 majority being subject to burial diagenesis only. The samples were collected from drillcores,

83 except for those from the Chuar Group and three Ediacaran/Cambrian shales from Svalbard.

84 Previous work has shown that Chuar shales have primary $\delta^{13} \mathrm{C}$ values, well-preserved Fe-

85 speciation chemistry, and preserved biomarker molecules (Summons et al., 1988; Dehler et al.,

86 2005; Johnston et al., 2008), suggesting that late stage alteration/oxidative weathering was

87 minimal.

88 For bulk quantitative mineralogical analyses, hand selected shale samples were lightly

89 pre-crushed in an aluminum mortar and pestle; 10 wt. \% reagent grade ZnO (Alfa Aesar;

90 confirmed to be pure Zincite by powder XRD) was added to each sample (0.1111g ZnO per

91 gram of sample) as an internal standard for quantitative analyses. Samples were then ground in a

92 Spex (\#8507) hardened steel shatterbox container and swing mill (at 1 minute intervals), with

93 Vertrel XF fluorocarbon used as a grinding aid to attain particle sizes below $10 \mu \mathrm{m}$. The

94 shatterbox was cleaned with ultra-pure quartz and "pre-contaminated" by grinding a small 95 amount of sample prior to treatment.

96 For separation and powder XRD analysis of clay-mineral fractions, we used a modified 97 procedure after Moore \& Reynolds (1997) to separate the $<2 \mu \mathrm{m}$ particle size fraction. Isolation 
98 of the $<2 \mu \mathrm{m}$ particle size fraction was performed using separate bulk rock samples (that were 99 disaggregated by hand) than those used for bulk mineralogical analyses.

Acquisition of powder X-ray diffraction patterns (XRD) was performed with a Scintag

101 XDS 2000 diffractometer (Cu Ko radiation). Data were collected in step sizes of $0.02^{\circ} 2 \Theta$ with

102 counting time ranging from 2-4 seconds for bulk powders and clay-sized fractions. Background

103 stripping, indexing of diffraction peaks and mineral identification was performed using

104 Crystallographica Search-Match software (Oxford Cryosystems). Divergent slit sizes of 1 and $1052 \mathrm{~mm}$, and receiving slit sizes of 0.5 and $0.3 \mathrm{~mm}$ were used for all analyses.

106 Randomly-oriented powder mounts were prepared for bulk mineralogical analyses using 107 a modified back-drift method as described in Moore \& Reynolds (1997). For the analysis of 108 oriented clay fractions $(<2 \mu \mathrm{m}$ particle size), samples were prepared on glass slides following a 109 millipore filter-peel technique (Drever, 1973). Treatment with ethylene glycol involved sealing 110 prepared slides in a glass desiccator containing ethylene glycol liquid overnight at $65^{\circ} \mathrm{C}$.

111 After initial mineral phases were identified, quantitative abundances were determined 112 with RockJock software (Eberl, 2003). The program compares integrated X-ray intensities for 113 minerals present in a sample with that of the internal standard $(\mathrm{ZnO})$ and weight percentages are 114 calculated using previously measured peak intensity factors (Eberl, 2003). The RockJock 115 quantitative calculations have been checked for accuracy using predetermined mineral mixtures 116 and generally give values to within a precision of 1 to $2 \%$. In addition, abundances for each 117 mineral are calculated independently with respect to the internal $\mathrm{ZnO}$ standard and so a total 118 value of close 100 wt. \% serves as an independent check on the accuracy of calculations. We 119 only accepted calculations that yielded a "degree of fit" less than 0.11 . For the determination of 120 clay mineral abundances, the program excludes peaks at $2 \Theta$ angles less than $20^{\circ}(\mathrm{Cu} \mathrm{K} \alpha)$ and 
121 instead uses high angle 060 reflections, which are less sensitive to preferred orientation effects

122 resulting from imperfect sample preparation (Srodon et al., 2001; Eberl, 2003). Each sample scan

123 was analyzed using the $20^{\circ}-65^{\circ} 2 \Theta$ range and the auto-background correction feature, allowing

124 mineral standards to be slightly shifted in $2 \Theta$ to maximize the degree of fit. The program is

125 freely available from the USGS at: ftp://brrcrftp.cr.usgs.gov/pub/ddeberl/. Results from

126 Crystallographica Search-Match and RockJock analyses were compared to analyses on oriented

127 (and glycolated) clay size fractions as a check for consistency.

128 The RockJock software generally produces accurate results when quantifying major

129 groups of clay minerals (i.e., kaolinite, 2:1 dioctahedral clays and chlorites). However,

130 quantitative assignment of polytypes (and species within these groups) is less reliable, and in

131 some cases the software produces false positive identification of phases and polytypes. For this

132 reason, where possible, ZnO-free randomly oriented powder XRD patterns were analyzed to

133 verify $1 M$ (possibly including $\left.1 M_{\mathrm{d}}\right)$ and $2 M_{1}$ illite polytypes using $h k l$ reflections at $32.1\left(2 M_{1}\right)$

134 and 24.3 degrees $2 \Theta(\mathrm{Cu} \mathrm{K \alpha})$ and the $2.58 \AA$ band, which is common to all illite polytypes

135 (Grathoff and Moore, 1996). The identification and estimate of $1 M$ and $1 M_{\mathrm{d}}$ illite polytypes is

136 complicated by the fact that their specific $h k l$ reflections often overlap. Thus an approximate

137 estimate for polytype percentage independent of RockJock software involves dividing the area of

138 the $32.1^{\circ}$ peak over the total area of the $2.58 \AA$ band (Grathoff and Moore, 1996; see electronic 139 annex). This analysis could not be done for all samples because of the difficulty in detecting 140 these weak polytype specific peaks, especially in cases where $2 M_{1}$ illite abundances were low. 141 Where it was possible, however, this allowed a check on RockJock determined polytype 142 assignments. Some inaccuracy is inescapable, but the stratigraphic coherence of large differences 143 found within our sample set suggests our data reflect real differences in clay content. 
In addition, for some samples, RockJock fits were slightly improved by the inclusion of

145 discrete smectite phases (Table 2). However, discrete smectite was not identified in any of the 146 oriented aggregate specimens analyses of the $<2 \mu \mathrm{m}$ size fraction, and so these quantities suggest 147 an effective detection limit for our RockJock analyses of 5 wt. \%.

148 For ethylene glycol treated oriented aggregates, the full width at half maximum of the

$14910 \AA$ peak was measured using WINFIT, a program for XRD profile fitting and size/strain 150 analysis (Krumm, 1996). For all peak decomposition analyses, line shapes were specified as 151 symmetrical and Gaussian. For oriented aggregates solvated with ethylene glycol, peak positions 152 were used to estimate the proportion of expandable smectite layers within illite found in our 153 samples. We follow Srodon (1980) and Moore \& Reynolds (1997) for approximating the 154 smectite component present in our analyses using the $\Delta 2 \Theta$ between the illite 001 / EG-smectite 155002 reflection and the illite 002 / EG-smectite 003 reflection.

TOC analyses were conducted on powdered bulk rock samples using the loss on ignition

157 (LOI) method outlined in Heiri et al. (2001), which involved drying overnight at $105^{\circ} \mathrm{C}$ and 158 heating to $550^{\circ} \mathrm{C}$. Most samples were run in duplicate as a check on reproducibility and the 159 averages of multiple analyses are reported in Table 2, and, in an effort to improve precision, 160 sample weights, heating temperatures, heating duration and oven placement were invariant for all 161 analyses (Heiri et al., 2001). Although using the LOI method as a measure of TOC in our 162 samples is subject to interference from structural water loss from hydrated clay minerals (Heiri et 163 al., 2001), the consistent lithology of our samples (fine-grained siliciclastic sediments with low 164 carbonate abundances) eliminates the effect of mineralogical heterogeneity and allows for more 165 reliable inter-sample comparison of TOC content. Although some water loss may be expected to 166 contribute to the overall LOI signal from hydrated mineralogy, for the most part these effects are 
167 anticipated to be small. For example, assuming an average of $50 \mathrm{wt} \%$ illite and using

168 unpublished data on illite structural water loss upon ignition (http://www-

169 usr.rider.edu/ hsun/carbon.pdf) the effects are expected to exhibit minor interference with only

170 the lowest TOC samples $(<1-2 \mathrm{wt} \%)$.

171 Bulk chemical analyses were performed using a Bruker S4 Pioneer wavelength dispersive

172 X-ray fluorescence spectrometer. Powdered bulk rock samples were pressed into pellets in a 173 cellulose matrix and analyses were performed using internal X-ray fluorescence standards.

175 3. Mineralogy and Geochemistry of Proterozoic Shales

$176 \quad 3.1$ Clay mineralogy through the Proterozoic Eon

177 Many clay minerals occur at the Earth’s surface, but the hallmark of Precambrian shales

178 is illite (Weaver, 1989). Illite forms under a variety of conditions and crystallizes in different

179 forms, or polytypes, that differ only in their crystallographic structure (Srodon and Eberl, 1984).

180 Most shales contain a mixture of illite polytypes. Commonly, illite in shales forms by the

181 diagenetic or metamorphic transformation of smectite and/or kaolinite (Srodon, 1999). With

182 temperature and/or time, this reaction progresses through mix-layered (e.g., illite/smectite)

183 species to clays that contain a high percentage of illite layers ( $85-95 \%$ illite) and few

184 smectite/kaolinite layers. This diagenetic illite consists almost exclusively of the $1 M$ and $1 M_{\mathrm{d}}$ 185 polytypes (referred to herein as $1 M / 1 M_{\mathrm{d}}$ illite) (Srodon, 1999). Thus, distinction can be made 186 between these polytypes and the $2 M_{1}$ mica-illite polytype (including muscovite) that generally 187 reflects clays formed by igneous and high-grade metamorphic processes and typically introduced 188 to sediments as detrital particles. The identification of $1 M / 1 M_{\mathrm{d}}$ illite polytypes, then, allows a 189 first-order estimate of the contribution of originally weathering-derived smectite and/or kaolinite 
190 to the mineral assemblage. However, clays derived from weathering in the regolith are not the 191 only source of $1 M / 1 M_{\mathrm{d}}$ illite. Volcanic material deposited in the ocean and/or on land rapidly 192 alters to smectite and this contribution could overprint a soil-borne clay component especially 193 when integrated over the significant timescales captured by our sample set (Weaver, 1989). That 194 noted, we know of no distribution of volcanic components, either in the shales we collected or in 195 the basins we sampled, that could explain the stratigraphic distribution $1 M / 1 M_{\mathrm{d}}$ illites reported 196 below. Clay formed from diagenetic reactions, in authigenic pore-filling cements from 197 sandstones and previously illitized mudstones may also complicate a weathering signal preserved 198 in ancient sedimentary rocks (Weaver, 1989; Meunier and Velde, 2004). Quantitative analysis of illite polytypes in our samples shows that a significant proportion 200 of the clay fraction (to a maximum of $\sim 70$ wt. \%) occurs as $1 M$ or $1 M_{\mathrm{d}}$ illite. Analyses of 201 ethylene-glycolated mineral separates further show that, with few exceptions, the percentage of 202 illite in mixed layered materials ranges from 85 to $>95 \%$, and discrete smectite is negligible or 203 non-existent. This suggests that, in nearly all samples illitization has reached an advanced stage. 204 Our samples also contain a significant component of $2 M_{1}$ illite (which, as discussed here, 205 includes muscovite; Figure 1; Table 2). As this mineral forms at temperatures well above any 206 experienced by all but the oldest of our sample set (e.g., $>275^{\circ} \mathrm{C}$; Table 1 ), its origin in nearly all 207 cases must be detrital. Other clays in our samples typically include glauconite, chlorite, and 208 minor amounts of kaolinite (Table 2). “Glauconite”, as used here, is defined operationally based 209 on the position of the 060 XRD peak and decomposition of 001 peaks; it includes not only true 210 glauconites, but those species which can be collectively classified as Fe-rich 2:1 clays (Srodon et 211 al., 2001). 
Glauconite was identified in most samples (Table 2; Fig. 2). Glauconite is generally

213 thought to form by the recrystallization of a precursor material (usually Fe-rich) under typically

214 reducing conditions, and this reaction must occur near the sediment-water interface in contact

215 with seawater derived $\mathrm{K}$ to allow $\mathrm{K}_{2} \mathrm{O}$ incorporation and the formation of glauconitic mica

216 (Rousset et al., 2004; Meunier and El Albani, 2007). The precursor may form as an intermediate

217 phase during early diagenesis and glauconitization, or it may be composed of detrital material

218 that reacted with ambient chemistry in the sediment. Nevertheless, the origins of glauconite

219 most clearly represent specific physical/chemical conditions (i.e., reducing, seawater K diffusion

220 and low sedimentation rate) during early diagenesis (Velde, 2003; Rousset et al., 2004).

221 The most noticeable changes in clay mineralogy occur among samples from late

222 Neoproterozoic basins (Figures 1 \& 2). Compared to samples from the late Archean and

223 Mesoproterozoic, most late Neoproterozoic samples show a significant increase in the proportion

224 of $2 M_{1}$ illite (including muscovite) in the clay fraction (Figure 1). The proportion of $1 M / 1 M_{\mathrm{d}}$

225 illite and glauconite shows a corresponding decrease within the same basins (Figure 2), reflecting

226 an effective switch in the dominant phyllosilicate phase in these late Neoproterozoic samples,

227 with total clay content remaining more or less constant.

228 In our samples, smectites are essentially undetectable; however, a major fraction of

$2291 M / 1 M_{\mathrm{d}}$ illite in our samples probably represents the transformation of pre-existing smectite

230 and/or kaolinite in the original clay assemblage. Thus, non-detection of smectite most likely

231 reflects burial diagenesis and not original absence. From this, we conclude that clay-rich

232 weathering products were common throughout the Proterozoic Eon, in line with previous studies

233 of Precambrian shales that also report significant diagenetic $1 M / 1 M_{\mathrm{d}}$ illite (Reynolds, 1963, 1965;

234 Weaver, 1967, 1989; Eslinger and Sellars, 1981). 


\subsection{Paleo-weathering indices and K-metasomatism}

$238 \mathrm{~K}$ relative to $\mathrm{Al}$ and, in some cases, Fe. Mineralogically, progressive Al-enrichment is reflected

239 by the formation of smectite and Al-bearing clay minerals in the residual weathered materials

240 (Nesbitt and Young, 1989; Nesbitt and Markovics, 1997). The net effect of chemical weathering,

241 then, is the conversion of feldspar to smectite and, with continued and/or more intense leaching,

242 Al-rich clays such as gibbsite and kaolinite. These changes are most effectively uncovered using

243 a $\mathrm{Al}_{2} \mathrm{O}_{3}-\left(\mathrm{CaO} *+\mathrm{Na}_{2} \mathrm{O}\right)-\mathrm{K}_{2} \mathrm{O}$ ternary plot (here, referred to as $\mathrm{A}-\mathrm{CN}-\mathrm{K}$ ) of molar oxide

244 proportions, where $\mathrm{CaO}^{*}$ is silicate $\mathrm{CaO}$ only (the $\mathrm{CaO}$ correction includes removal of

245 carbonate-associated $\mathrm{Ca}$, as well as phosphate-associated CaO. More details of the correction can

246 be found in Fedo et al. (1995)). The chemical trends of modern and ancient weathering profiles

247 are indistinguishable to those predicted from thermodynamic and kinetic data (Nesbitt and

248 Young, 1984; Nesbitt et al., 1997). This relationship requires that the predicted chemical

249 weathering trend of a given source rock composition on the A-CN-K diagram evolve along a 250 path parallel to the A-CN join (see Figure 3). With continued and/or more intense weathering,

251 after intersection with the $\mathrm{A}-\mathrm{K}$ join, the trend continues to the $\mathrm{Al}_{2} \mathrm{O}_{3}$ apex where the soil 252 mineralogy is dominated by aluminous phases (Figure 3). Quantitatively, the degree of 253 weathering is expressed by the chemical index of alteration (CIA), where:

$$
\mathrm{CIA}=\left[\mathrm{Al}_{2} \mathrm{O}_{3} /\left(\mathrm{Al}_{2} \mathrm{O}_{3}+\mathrm{CaO} *+\mathrm{Na}_{2} \mathrm{O}+\mathrm{K}_{2} \mathrm{O}\right)\right] * 100
$$

255 On the A-CN-K diagram, the CIA is simply a projection on the vertical $\left(\mathrm{Al}_{2} \mathrm{O}_{3}\right)$ axis (Figure 3).

256 Unweathered feldspar-rich source rocks display CIA values near 50 and the value increases with 257 the intensity of chemical weathering. 
The effects of burial metamorphism and metasomatism obscure these primary weathering

259 trends. Upon burial diagenesis and heating, the predominant chemical change is $\mathrm{K}$ -

260 metasomatism in two forms: (1) K-addition to aluminous products -- for example, the addition of

$261 \mathrm{~K}$ to kaolinite/smectite to produce metamorphic illite, and (2) the substitution of K for Ca or Na

262 in plagioclase (Fedo et al., 1995). On the A-CN-K diagram, the net effect of these reactions is to

263 drive each weathered sample toward the $\mathrm{K}_{2} \mathrm{O}$ apex in the case of K-addition to aluminous

264 products, or to drive the sample horizontally to the A-K join in the case of K-substitution (Figure

265 3). Aside from $\mathrm{K}$, diagenetic processes have been shown to cause the redistribution of $\mathrm{Ca}, \mathrm{Mg}$,

$266 \mathrm{Na}, \mathrm{Fe}, \mathrm{Si}$ and possibly Al, but the scale at which these elements are mobile and the degree to

267 which such systems can be considered open remains unresolved (McLennan et al., 2003).

268 Nevertheless, the bulk of fine-grained siliciclastics that have been analyzed in A-CN-K ternary

269 space show that illitization results in a net offset toward the $\mathrm{K}_{2} \mathrm{O}$ axis (Fedo et al., 1995, 1996,

270 1997; Bloch et al., 2006). This suggests that K may be considered highly mobile in fine-grained

271 illitization systems at the basinal scale (e.g., Furlan et al., 1996) -- more so than Al, which is

272 redistributed through isomorphic substitution and limited to exchange between primary and 273 secondary mineral phases.

274 Given these relationships, if source composition is known or can be inferred, a predicted

275 "pre-metamorphic" weathering trend can be calculated. The effects of K-metasomatism can then 276 be removed by extending a vector from the $\mathrm{K}_{2} \mathrm{O}$ apex through each sample to the predicted 277 chemical weathering trend (Fedo et al., 1995). Thus, the present day CIA value is corrected for 278 metamorphic effects and a "paleo-CIA" value can be estimated for a given sample (Figure 3).

279 Our late Archean and Mesoproterozoic samples plot close to the A-K join on an array 280 that extends away from a portion of the A-CN join defined by smectite-kaolinite mixing (Figure 
281 4). None of the late Archean or Mesoproterozoic basins define a trend that is subparallel to a 282 predicted chemical weathering pathway. Assuming a pre-weathered source composition 283 equivalent to average late Archean upper crust (Condie, 1993; Fedo et al., 1995), we can define a 284 weathering trend for samples unaffected by K-metasomatism (Figure 4). Applying corrections to 285

286 have estimated paleo-CIA values for each sample (Figure 4; Table 2). The assumption of an 287 upper crustal source composition and the observed positions of our late Archean and 288 Mesoproterozoic samples on Figure 4 requires a significant degree of K-enrichment. 289 Mineralogical evidence suggests that these samples could have experienced the highest degrees 290 of K-addition; $1 M / 1 M_{\mathrm{d}}$ illite abundances (and glauconite) are among the highest measured in our 291 sample set (Table 2). In addition, the illite 001 XRD peaks are among the broadest measured; 292 this is inconsistent with illite derivation largely from magmatic processes and points to K293 addition to chemical weathering and/or diagenetic products.

294 Late Archean samples yield paleo-CIA values of 81-86+ (with one exception, 68), 295 consistent with intense weathering and leaching. Our results are, thus, in agreement with a 296 number of studies that report high paleo-CIA values for siliciclastics of this age (Fedo et al., 297 1996; Bhat and Ghosh, 2001; Condie et al., 2001; Hessler and Lowe, 2006). In fact, it has long 298 been recognized that Archean shales are enriched in $\mathrm{K}_{2} \mathrm{O}$ relative to estimates of average upper 299 crust (McLennan et al., 1983). The consistently high paleo-CIA of Archean and Paleoproterozoic 300 rocks (see Condie et al. (2001) for a compilation; Fig. 6) reflect intense leaching and weathering 301 processes perhaps driven by elevated $p \mathrm{CO}_{2}$ (Holland, 1984; Hessler and Lowe, 2006). In such an 302 environment, residual Al-rich species such as kaolinite and gibbsite would have dominated the 303 clay assemblage. For our Mesoproterozoic shales from Northern Australia, we calculate paleo- 
304 CIA values of 71-85, reflecting more moderate weathering involving metal retention and 305 concomitant $\mathrm{pH}$ increase, a regime that typically favors smectite production.

306 Neoproterozoic samples are significantly more scattered than late Archean and

307 Mesoproterozoic samples (Figure 5). In addition, inferred source rock compositions are more

308 diverse and complex, ranging from granodioritic (roughly equivalent to the average Upper

309 Neoproterozoic crust) to more K-enriched charnockitic. Some Neoproterozoic and early

310 Cambrian sample suites define a clear trend from an unweathered source composition, but in

311 others such a trend is difficult to discern. For these latter samples we choose unweathered source

312 compositions based on mineralogical constraints as much as possible (see electronic annex for a

313 sample-by-sample discussion), but we also record corresponding “maximum” paleo-CIA values

314 relative to an average crustal source in Table 2. It should be noted that the choice of a more

315 mafic crustal source is incompatible with the mineralogical characteristics measured in most

316 Neoproterozoic samples. In short, samples from most of the Neoproterozoic basins sampled in

317 this study exhibit lower paleo-CIA values than those collected from Mesoproterozoic and late

318 Archean basins (Figure 6), even when maximum estimates based purely on an upper crustal

319 source composition (Table 2) are used. This is consistent with the marked change in clay 320 mineralogy seen in these same samples.

321

322 4. Mineralogical and geochemical associations with organic carbon

$323 \quad 4.1$ Paleo-CIA and TOC

324 It is tempting to ask whether an increase in the proportion of igneous phyllosilicates seen

325 in our late Neoproterozoic samples could lead to more efficient burial and sequestration of 326 organic carbon. However, we observe no correlation between the amount of igneous 
327 phyllosilicates (i.e., muscovite, $2 M_{1}$ illite) and TOC. On the other hand, paleo-CIA shows a weak 328 positive correlation with TOC (Spearman rank correlation coefficient $\left(\mathrm{r}_{\mathrm{s}}\right)=0.208, \mathrm{P}=0.063$;

329 Figure 7). As discussed above, the chemical weathering conditions that lead to efficient smectite 330 production do not necessarily correlate with weathering intensity, or paleo-CIA; the CIA values 331 that correspond to the highest potential smectite abundances instead lie between 70 and 82 (see 332 Fig. 3). Indeed, our highest TOC samples lie within this range; they are the most likely to have 333 been influenced by moderate paleo-weathering conditions and efficient smectite generation 334 (Figure 7). With increasing weathering intensity beyond the smectite-dominated range, leaching 335 begins to dominate and smectite minerals are destabilized, giving way to aluminous products. 336 Samples residing at this end of the CIA values generally show decreased TOC content, but two 337 of the highest TOC samples also have the highest paleo-CIA, suggesting that aluminous clay 338 mineralogy does not preclude high OM content upon burial (Figure 7). Although a robust metric 339 for the quantity and type of clays derived from chemical weathering is difficult to derive for such 340 a sample suite, this correlation suggests that the characteristics of smectite-rich soils may have 341 increased the effectiveness of organic carbon burial (e.g., Mayer, 1994; Ransom et al., 1998).

342 Additionally, our highest TOC (and the most intensely weathered) samples are pre343 Ediacaran in age. Although our sample set is biased toward high TOC, this observation is in 344 broad agreement with TOC compilations among shales spanning the Proterozoic; a survey of 345 1800 shales showed that average TOC is highest among Paleo- and Mesoproterozoic samples 346 (10.3 and $13.4 \mathrm{mg} / \mathrm{g}$, respectively) and decreases into the Neoproterozoic ( $4.7 \mathrm{mg} / \mathrm{g}$ ) (Strauss et 347 al. (1992)). 


\subsection{Illite crystallinity: Constraints on the physical association between clays and OM}

Empirical measures of illite "crystallinity” (IC) have been widely used as indicators of thermal history (Srodon and Eberl, 1984; Meunier, 2005), but they may contain additional information on clay-OM interactions. Illite "crystallinity,” measured by $10 \AA ̊$ XRD peak widths, reflects a combination of three mineral components: $2 M_{1}$ mica-illite, $1 M / 1 M_{\mathrm{d}}$ illite (including mixed layer I/S) and glauconite. The full width at half-maximum (FWHM) of the $10 \AA$ peak is controlled mainly by: (1) crystallite-size distribution, (2) the number of expandable layers present in the illite and (3) any structural defects or distortions present in the crystals (Eberl and Velde, 1989). Because almost all of our samples are composed of illite that contains only a small proportion of expandable smectite layers (5-15\% maximum), we can discount any significant contribution of I/S expandability to the FWHM of the $10 \AA$ peak (Eberl and Velde, 1989; Suchy et al., 2007). Accordingly, the larger FWHM values can be taken to be representative of a greater proportion of smaller or poorly crystalline illite crystallites.

Analyses show that the FWHM of the $10 \AA$ peak correlates strongly $\left(r_{\mathrm{s}}=0.598, \mathrm{P}=\right.$ $2.3 \times 10^{-4}$ ) with total organic carbon (TOC) content (Figure 8). Because several basins each contain samples spanning almost the entire range of this correlation, we can eliminate any thermal effects of diagenesis or metamorphism on this relationship. In fact, samples from the Mt. McRae shale span $30 \mathrm{~m}$ of drill core (and so have an imperceptible metamorphic gradient), but encompass the entire range of this correlation.

The principal controls on IC are not straight-forward, but the metric weakly correlates with increasing amounts of the illite $1 M$ and $1 M_{\mathrm{d}}$ polytypes and glauconite $\left(\mathrm{r}_{\mathrm{s}}=0.551, \mathrm{P}=\right.$ $6.8 \times 10^{-4}$; see electronic annex). There is also a weak negative correlation between IC and $2 M_{1}$ illite content $\left(r_{\mathrm{s}}=-0.158, \mathrm{P}=0.37\right)$, indicating that increasing amounts of coarse (detrital) $2 M_{1}$ 
373 illite probably play a small role in decreasing the overall width of the $10 \AA$ illite XRD peak (see

374 electronic annex). The IC-TOC association is significant because the $1 M / 1 M_{\mathrm{d}}$ illite polytypes

375 mainly occur through the transformation of smectite/kaolinite precursors. On the other hand,

376 detrital $2 M_{1}$ mica-illite seems to have little direct association with organic matter, implicating

377 weathering-derived (but since transformed) clays in OM burial.

378 Studies of OM association with clays in modern marine settings offer insight into 379 mechanisms responsible for the IC-TOC association in our samples. Detailed HR-TEM analyses 380 of continental margin sediments off of the California coast have revealed that the physical 381 association between OM and smectite initially occurs through the formation of OM-clay flocs 382 (Ransom et al., 1997, 1998). Upon deposition in seawater, fine clay crystals tend to flocculate 383 and form aggregates that incorporate significant amounts of OM (Ransom et al., 1998). In the 384 aggregates, the OM tends to be irregularly distributed, occurring as blebs and smears intimately 385 associated with clays (Ransom et al., 1997; Curry et al., 2007). The result of OM incorporation is 386 a significant decrease in permeability, in part from a greater percentage of pore space being 387 occupied by OM and the subsequent creation of inaccessible micro-porosity (Curry et al., 2007). 388 This physical association has been suggested to lead to greater preservation potential of OM 389 matter by inhibiting enzymatic breakdown; the enzyme-controlled degradation becomes 390 diffusion limited and much of the OM occupies pore space inaccessible to the reactants (Ransom 391 et al., 1998; Rothman and Forney, 2007). Causality may run in more than one direction, however; 392 OM physically interferes with the illite formation process, preserving small crystallite size. 393 Although there are few data in the literature that report both illite crystallinity and TOC, positive 394 relationships are observed for both Proterozoic and Phanerozoic rocks, but only when TOC 395 concentrations extend beyond 1 wt. \% (Underwood et al., 1989; Yang and Hesse, 1991; Sucha 
396 et al., 1994; Uysal et al., 2004). Further evaluating potential IC-TOC relationships involves

397 making the distinction between primary and diagenetic influences by ruling out any possible 398 thermal effects, as discussed above.

399 Illitization is thought to occur by a number of different mechanisms, but three have 400 gained acceptance: (1) solid-state transformation (SST) of smectite layers to illite layers, (2) 401 smectite dissolution and illite crystallization (DC), and (3) Ostwald ripening (Altaner and Ylagan, 402 1997). The dominant mechanism(s) for illitization in a given setting is thought to be a function of 403 sediment permeability (Altaner and Ylagan, 1997; Srodon, 1999). For example, sandstones are 404 typically characterized by the DC mechanism whereas illitization in lower permeability 405 bentonites proceeds by the SST mechanism. Shales and other fine-grained siliciclastic rocks have 406 been shown to exhibit both SST and DC mechanisms, which reflects the variable mineralogy, 407 burial conditions and hydrothermal reactions experienced after deposition. The most important 408 feature of these two mechanisms, however, is that the SST mechanism preserves parent crystal 409 size, morphology and polytype (Altaner and Ylagan, 1997). In contrast, the DC mechanism 410 results in larger crystals and destruction of parent crystal morphology and polytype. In other 411 words, illitization by SST is largely a function of sediment permeability. Based on these 412 observations, higher OM content is likely to interfere with illitization by lowering local 413 permeability, fostering the probability of solid-state illitization. The final result is the 414 preservation of small crystallite size, largely determined by the original mode of flocculation and 415 aggregation of OM-clay particles, and later by burial and compaction.

416 The suggestion that OM may have inhibited recrystallization of illite during diagenesis is 417 not a new one. In fact, Jackson (1977) found that his sample set (comprised of a number of fine418 grained siliciclastics spanning the Proterozoic) displayed a positive correlation between illite 
419 crystallinity and the degree of OM humification. The original interpretation was that although

420 burial diagenesis is known to increase OM condensation (leading to a decrease in aliphatic and

421 polar groups), the variations were primary, or pre-determined by OM-clay interactions, perhaps

422 leading to an interference of $\mathrm{OM}$ on illitization. In the end, the correlation between illite

423 crystallinity and TOC may reflect both the facilitation of OM sequestration by poorly crystalline

424 illite with high surface area (Bock and Mayer, 2000) and the impedance of diagenetic illitization

425 by OM incorporation.

426

\section{Physical and chemical weathering through the Neoproterozoic Era}

Most siliciclastic successions display marked chemical variation, reflecting the dynamic

429 interplay of chemical weathering, physical erosion and diagenetic/metamorphic processes

430 (McLennan et al., 1993; Nesbitt et al., 1997). In particular, the balance between rates of chemical

431 weathering and physical erosion exerts a major control on the geochemistry and mineralogy of

432 siliciclastic rocks (Nesbitt et al., 1997). The general consistency of paleo-CIA values over a

433 billion years of Late Archean through Mesoproterozoic time, thus, suggest long term balance in

434 weathering and erosion rates. Low paleo-CIA values obtained for two early Neoproterozoic

435 Chuar Group shales might simply identify outliers in a statistical distribution like that of earlier

436 intervals. Paleo-CIA values for Ediacaran to basal Cambrian shales, however, cannot be

437 explained this way. These samples are statistically different from older shales $\left(\mathrm{p}=9.4 \times 10^{-9}\right.$;

438 Student's t-test), requiring perturbation in the rates of chemical weathering and/or physical

439 erosion in response to climatic shifts or tectonism (Nesbitt et al., 1997).

Lower paleo-CIA values could reflect Ediacaran increases in rates of erosion and

441 (concomitantly) sediment accumulation. For example, Squire et al. (2006) have hypothesized 
442 that sediment accumulation rates increased in response to large-scale Pan-African uplift (Squire

443 et al., 2006). Increased physical erosion of uplifted terrains would tend to drive CIA lower, 444 allowing for a greater proportion of igneous/detrital clay relative to clay formed through 445 weathering in the regolith.

446 In contrast, hypotheses of increased chemical weathering on Ediacaran continents are at 447 odds with our data (Kennedy et al., 2006). The increasing weathering hypothesis was based on 448 the XRD analyses of siliciclastic rocks spanning the latest Neoproterozoic; Kennedy et al. (2006) 449 supported their hypothesis by reporting the Schultz Ratio, a ratio of the 020 XRD peak $\left(19.8^{\circ} 2 \Theta\right.$; $450 \mathrm{CuK} \alpha$ ), which all phyllosilicates (weathering-derived, detrital or igneous) exhibit, to the 100 451 XRD peak (20.8 $2 \Theta$; CuK $\alpha$ ), which only quartz exhibits. Although our results clearly show an 452 increase in the proportional abundance of mica and $2 M_{1}$ illite in the clay fraction of Ediacaran 453 and basal Cambrian shales, we observe no increase in absolute clay mineral content (see 454 electronic annex). Thus, at the sample level, increased detrital contributions appear to be 455 compensated by decreased input from chemical weathering products. The relative abundance of 456 quartz in the non-clay fraction also decreases markedly in our latest Neoproterozoic samples (see 457 electronic annex). This is consistent with an influx of chemically immature sediments, but may 458 not be directly reflective of this because XRD analysis cannot differentiate between sedimentary 459 quartz and later cements.

460 Figure 9 shows the Schultz ratio from our samples plotted as a function of age. A 461 proportional decrease in quartz and concomitant increase in igneous and metamorphic 462 phyllosilicates (i.e., muscovite and $2 M_{1}$ illite) readily accounts for the observed increase in the 463 Schultz ratio (note that igneous clays and quartz strongly diffract X-rays in powder X-ray 464 diffraction; Moore and Reynolds, 1997). Moreover, Figure 10 shows that, regardless of any 
465 secular decrease in quartz, $2 M_{1}$ illite and mica minerals are the principal controls on Schultz ratio 466 in all of our samples (with the exception of chlorite-rich late Archean shales). Although the $2 M_{1}$

467 illite observed in our samples might be blamed on original clay-rich weathering products that 468 were transformed in a prior rock cycle, major element geochemistry shows that these samples 469 were relatively unweathered at the time of sedimentation.

470 In total, then, the mineralogy and geochemistry of our sample set are consistent with the 471 analyses reported by Kennedy et al. (2006), but we suggest that decreased weathering, probably 472 tied to increased rates of uplift and physical erosion, can account for observed secular variation 473 without invoking any change in land vegetation or increased rates of chemical weathering.

474 To summarize, relative to chemical weathering, physical erosion dominates samples 475 across the Proterozoic-Cambrian boundary leading to a significant influx of detritally borne (and 476 relatively unweathered) micaceous clay-bearing sediment. Mesoproterozoic samples provide 477 multiple lines of evidence for moderate chemical weathering conditions (CIA $=70-85)$ that were 478 the most conducive to smectite mineral generation; and late Archean samples show more intense 479 weathering and leaching conditions $(\mathrm{CIA}=90+)$ leading to residual enrichment of Al-rich 480 products before burial metamorphism. Whereas clay minerals undoubtedly played a role in OM 481 burial throughout Earth history, our data provide little support for the idea that changes in the 482 rate of clay formation in the regolith were principal drivers of Proterozoic oxygenation.

484 Acknowledgements: We thank W. Croft, S. Jacobsen and J. Quinn for use of, and assistance 485 with, laboratory and analytical facilities and A. Smirnov, W. Xu and A. Kelly for assistance with 486 analyses and sample collection. We also thank Scott McLennan and Jon Wilson for helpful 487 discussions, and Larry Mayer, two anonymous reviewers, and Tim Lyons for thorough and 
488

489

490

491

492

493

constructive reviews. Research supported in part by a Harvard Origins Postdoctoral Fellowship

to N.J.T., a Harvard MSI Postdoctoral Fellowship to D.T.J., a NASA Exobiology grant NNX07AV51G to D.T.J. and A.H.K. and a NSF Biocomplexity grant EAR-0420592 to D.H.R., R.E.S., and A.H.K. D.H.R. thanks the Radcliffe Institute for Advanced Study for yearlong fellowship support.

\section{References:}

Altaner, S. P. and R. F. Ylagan 1997. Comparison of structural models of mixed-layer illite/smectite and reaction mechanisms of smectite illitization. Clays and Clay Minerals 45(4): 517-533.

Bhat, M. I. and S. K. Ghosh 2001. Geochemistry of the 2.51 Ga old Rampur group pelites, western Himalayas: implications for their provenance and weathering. Precambrian Research 108(1): 1-16.

Bloch, J. D., J. M. Timmons, et al. 2006. Mudstone petrology of the Mesoproterozoic Unkar Group, Grand Canyon, USA: Provenance, weathering, and sediment transport in intracratonic Rodinia. Journal of Sedimentary Research 76(9): 1106-1119.

Bock, M. J. and L. M. Mayer 2000. Mesodensity organo-clay associations in a near-shore sediment. Marine Geology 163: 65-75.

Canfield, D. E. 2005. The early history of atmospheric oxygen: Homage to Robert A. Garrels. Annual Review of Earth and Planetary Sciences 33: 1-36.

Catling, D. C. and M. W. Claire 2005. How Earth's atmosphere evolved to an oxic state: A status report. Earth and Planetary Science Letters 237(1): 1-20.

Cloud, P. 1976. Beginnings of biospheric evolution and their bio-geochemical consequences. Paleobiology 2(4): 351-387.

Condie, K. C. 1993. Chemical composition and evolution of the upper continental crust: Contrasting results from surface samples and shales. Chemical Geology 104: 1-37.

Condie, K. C., D. J. Des Marais, et al. 2001. Precambrian superplumes and supercontinents: a record in black shales, carbon isotopes, and paleoclimates? Precambrian Research 106(3): 239-260.

Curry, K. J., R. H. Bennett, et al. 2007. Direct visualization of clay microfabric signatures driving organic matter preservation in fine-grained sediment. Geochimica et Cosmochimica Acta 71: 1709-1720.

Dehler, C. M., M. B. Elrick, et al. 2005. High-resolution $\delta^{13} \mathrm{C}$ stratigraphy of the Chuar Group (ca. 770-742 Ma), Grand Canyon: Implications for mid-Neoproterozoic climate change. Geological Society of America Bulletin 117(1/2): 32-45.

Des Marais, D. J., H. Strauss, et al. 1992. Carbon isotope evidence for the stepwise oxidation of the Proterozoic environment. Nature 359: 605.

Drever, J. I. 1973. The preparation of oriented clay mineral specimens for X-ray diffraction analysis by a filter-membrane peel technique. American Mineralogist 58: 553-554. 
Eberl, D. D. 2003. A user's guide to RockJock - A program for determining quantitative mineralogy from powder X-ray diffraction data. U.S. Geological Survey Open-File Report 03-78. Boulder, CO, U.S. Geological Survey: 47.

Eberl, D. D. and B. Velde 1989. Beyond the Kubler Index. Clay Minerals 24(4): 571-577.

Eslinger, E. and B. Sellars 1981. Evidence for the formation of illite from smectite during burial metamorphism in the Belt Supergroup, Clark Fork, Idaho. Journal of Sedimentary Petrology 51(1): 203-216.

Fedo, C. M., K. A. Eriksson, et al. 1996. Geochemistry of shales from the Archean ( 3.0Ga) Buhwa greenstone belt, Zimbabwe: Implications for provenance and source-area weathering. Geochimica et Cosmochimica Acta 60(10): 1751-1763.

Fedo, C. M., H. W. Nesbitt, et al. 1995. Unraveling the effects of potassium metasomatism in sedimentary rocks and paleosols, with implications for paleoweathering conditions and provenance. Geology 23: 921-924.

Fedo, C. M., G. M. Young, et al. 1997. Potassic and sodic metasomatism in the Southern Province of the Canadian Shield: Evidence from the Paleoproterozoic Serpent Formation, Huronian Supergroup, Canada. Precambrian Research 84(1): 17-36.

Furlan, S., N. Clauer, et al. 1996. K transfer during burial diagenesis in the Mahakam Delta Basin (Kalimantan, Indonesia). Clays and Clay Minerals 44(2): 157-169.

Gaidos, E., T. Dubuc, et al. 2007. The Precambrian emergence of animal life: a geobiological perspective. Geobiology 5(4): 351-373.

Grathoff, G. H. and D. M. Moore 1996. Illite polytype quantification using WILDFIRE calculated X-ray diffraction patterns. Clays and Clay Minerals 44(6): 835-842.

Hayes, J. M., D. J. Des Marais, et al. 1992. Proterozoic Biogeochemistry. J. W. Schopf and C. Klein. Cambridge, Cambridge University Press: 1348.

Heiri, O., A. F. Lotter, et al. 2001. Loss on ignition as a method for estimating organic and carbonate content in sediments: reproducibility and comparability of results. Journal of Paleolimnology 25(101-110).

Hessler, A. and D. R. Lowe 2006. Weathering and sediment generation in the Archean: An integrated study of the evolution of siliciclastic sedimentary rocks of the 3.2 Ga Moodies Group, Barberton greenstone belt, South Africa. Precambrian Research 151(3): 185-210.

Holland, H. 1984. The Chemical Evolution of the Atmosphere and Oceans. Princeton, NJ, Princeton University Press.

Jackson, T. A. 1977. A relationship between crystallographic properties of illite and chemical properties of extractable organic matter in Pre-Phanerozoic and Phanerozoic sediments. Clays and Clay Minerals 25: 187-195.

Johnston, D. T., S. W. Poulton, et al. 2008. Early Neoproterozoic Ocean Chemistry: Fe-S Systematics from the Chuar Group. American Geophysical Union Meeting. San Francisco, CA, American Geophysical Union.

Kennedy, M., M. Droser, et al. 2006. Late Precambrian Oxygenation; Inception of the Clay Mineral Factory. Science 311: 1446-1449.

Kennedy, M., D. Pevear, et al. 2002. Mineral surface control of organic carbon in black shale. Science 295: 657-660.

Krumm, S. 1996. An interactive Windows progam for profile fitting and size/strain analysis. Materials Science Forum 228-331: 183-190.

Mayer, L. M. 1994. Surface-area control of organic-carbon accumulation in continental-shelf sediments. Geochimica et Cosmochimica Acta 58(4): 1271-1284. 
573

574

575

576

577

578

579

580

581

582

583

584

585

586

587

588

589

590

591

592

593

594

595

596

597

598

599

600

601

602

603

604

605

606

607

608

609

610

611

612

613

614

615

616

617

McLennan, S. M. 1993. Weathering and global denudation. Journal of Geology 101(2): 295-303.

McLennan, S. M., B. Bock, et al. 2003. The roles of provenance and sedimentary processes in the geochemistry of sedimentary rocks. Geochemistry of Sediments and Sedimentary Rocks: Evolutionary Considerations to Mineral Deposit-Forming Environments. D. R. Lentz, Geological Association of Canada. GeoText 4: 7-38.

McLennan, S. M., S. R. Hemming, et al. 1993. Geochemical approaches to sedimentation, provenance and tectonics. Processes controlling the composition of clastic sediments. M. J. Johnsson and A. Basu, Geological Society of America. Special Paper 284: 21-40.

McLennan, S. M., S. R. Taylor, et al. 1983. Geochemistry of Archean shales from the Pilbara Supergroup, Western Australia. Geochimica et Cosmochimica Acta 47: 1211-1222.

Meunier, A. 2005. Clays. Berlin, Springer.

Meunier, A. and A. El Albani 2007. The glauconite-Fe-illite-Fe-smectite problem: a critical review. Terra Nova 19: 95-104.

Meunier, A. and B. Velde 2004. Illite: Origins, Evolution and Metamorphism. Berlin, Springer.

Moore, D. M. and R. C. Reynolds Jr. 1997. X-ray diffraction and the identification and analysis of clay minerals. New York, Oxford University Press.

Nesbitt, H. W., C. M. Fedo, et al. 1997. Quartz and feldspar stability, steady and non-steady-state weathering, and petrogenesis of siliciclastic sands and muds. Journal of Geology 105: 173-191.

Nesbitt, H. W. and G. Markovics 1997. Weathering of the Toorongo Granodiorite, storage of elements in weathering profiles, and genesis of siliciclastic sediments. Geochimica et Cosmochimica Acta 61(8): 1653-1670.

Nesbitt, H. W. and G. M. Young 1984. Prediction of some weathering trends of plutonic and volcanic rocks based on thermodynamic and kinetic considerations. Geochimica et Cosmochimica Acta 48: 1523-1534.

Nesbitt, H. W. and G. M. Young 1989. Formation and diagenesis of weathering profiles. Journal of Geology 97: 129-147.

Nesbitt, H. W., G. M. Young, et al. 1996. Effects of chemical weathering and sorting on the petrogenesis of siliciclastic sediments, with implications for provenance studies. Journal of Geology 104: 525-542.

Ransom, B., R. H. Bennett, et al. 1997. TEM study of in situ organic matter on continental margins: occurrence and the "monolayer" hypothesis. Marine Geology 138: 1-9.

Ransom, B., D. Kim, et al. 1998. Organic matter preservation on continental slopes: Importance of mineralogy and surface area. Geochimica et Cosmochimica Acta 62(8): 1329-1345.

Ransom, B., K. Shea, et al. 1998. Comparison of pelagic and nepheloid layer marine snow: implications for carbon cycling. Marine Geology 150: 39-50.

Reynolds Jr., R. C. 1963. Potassium-rubidium ratios and polymorphism in illites and microclines from the clay size fractions of Proterozoic carbonate rocks. Geochimica et Cosmochimica Acta 27: 1097-1112.

Reynolds Jr., R. C. 1965. Geochemical behaviour of boron during the metamorphism of carbonate rocks. Geochimica et Cosmochimica Acta 29: 1101-1114.

Rothman, D. H. and D. C. Forney 2007. Physical model for the decay and preservation of marine organic carbon. Science 316: 1325-1328.

Rothman, D. H., J. M. Hayes, et al. 2003. Dynamics of the Neoproterozoic carbon cycle. Proceedings of the National Academy of Sciences of the USA 100(14): 8124-8129. 
618

619

620

621

622

623

624

625

626

627

628

629

630

631

632

633

634

635

636

637

638

639

640

641

642

643

644

645

646

647

648

649

650

651

652

653

654

655

656

657

658

659

660

661

662
Rousset, D., S. Leclerc, et al. 2004. Age and origin of albian glauconites and associated clay minerals inferred from a detailed geochemical analysis. Journal of Sedimentary Research 74(5): 631-642.

Squire, R. J., I. H. Campbell, et al. 2006. Did the Transgondwanan Supermountain trigger the explosive radiation of animals on Earth? Earth and Planetary Science Letters 250: 116133.

Srodon, J. 1980. Precise identification of illite/smectite interstratifications by X-ray powder diffraction. Clays and Clay Minerals 28: 401-411.

Srodon, J. 1999. Nature of mixed-layer clays and mechanisms of their formation and alteration. Annual Review of Earth and Planetary Sciences 27: 19-53.

Srodon, J., V. A. Drits, et al. 2001. Quantitative X-ray diffraction analysis of clay-bearing rocks from random preparations. Clays and Clay Minerals 49(6): 514-528.

Srodon, J. and D. D. Eberl 1984. Illite. Micas. Washington, D.C., Mineralogical Society of America. 13: 495-544.

Strauss, H., D. J. Des Marais, et al. 1992. Concentrations of Organic Carbon and Maturities and Elemental Compositions of Kerogens. The Proterozoic Biosphere. J. W. Schopf and C. Klein, Cambridge, pp. 95-99.

Sucha, V., L. Kraus, et al. 1994. Ammonium illite from anchimetamorphic shales associated with anthracite in the Zemplinicum of the Western Carpathians. Clay Minerals 29: 369-377.

Summons, R.E., S.C. Brassell, et al. 1988. Distinctive hydrocarbon biomarkers from fossiliferous sediment of the late Proterozoic Walcott Member, Chuar Group, Grand Canyon, Arizona. Geochimica et Cosmochimica Acta 52: 2625-2637.

Suchy, V., I. Sykorova, et al. 2007. Illite "crystallinity:, maturation of organic matter and microstructural development associated with lowest-grade metamorphism of Neoproterozoic sediments in the Tepla-Barrandian unit, Czech Republic. Clay Minerals 42: 503-526.

Taylor, G. and R. A. Eggleton 2001. Regolith Geology and Geomorphology. Wiley, West Sussex, UK; 375 pp.

Underwood, M. B., M. M. Laughland, et al. 1989. Thermal maturity and organic geochemistry of the Kandik Basin region, east-central Alaska. U.S. Geological Survey Open-File Report. Menlo Park, CA, U.S. Geological Survey: 44.

Uysal, I. T., M. Glikson, et al. 2004. Hydrothermal control on organic matter alteration and illite precipitation, Mt. Isa Basin, Australia. Geofluids 4: 131-142.

Velde, B. 2003. Green clay minerals. Treatise on Geochemistry. H. D. Holland and K. K. Turekian, Elsevier. 7: 309-324.

Weaver, C. E. 1967. Potassium, illite and the ocean. Geochimica et Cosmochimica Acta 31: 2181-2196.

Weaver, C. E. 1989. Clays, Muds, and Shales. New York, Elsevier.

Yang, C. and R. Hesse 1991. Clay minerals as indicators of diagenetic and anchimetamorphic grade in an overthrust belt, external domain of southern Canadian Appalachians. Clay Minerals 26: 211-231. 
663 Table 1: Ages, formations, geographic locations, and thermal histories of samples discussed in 664 this study.

\begin{tabular}{|c|c|c|c|c|c|}
\hline Sample ID & Age (Ma) & Formation & Location & Sample Type & Thermal \\
\hline GKPO1 248.09 & $2520-2500$ & Kleine Naute & S. Africa & DC & $\mathrm{a}, \mathrm{d}, \mathrm{e}$ \\
\hline GKPO1 483.90 & $2600-2520$ & Nauga & S. Africa & DC & $\mathrm{a}, \mathrm{d}, \mathrm{e}$ \\
\hline GKPO1 385 & $2600-2520$ & Nauga & S. Africa & DC & $\mathrm{a}, \mathrm{d}, \mathrm{e}$ \\
\hline GKPO1 1017 & $2650-1600$ & Monteville & S. Africa & DC & $a, d, e$ \\
\hline GKPO1 893.1 & ca 2600 & Reivilo & S. Africa & DC & $\mathrm{a}, \mathrm{d}, \mathrm{e}$ \\
\hline ABDP-9 149.30 & $2510-2500$ & Mt. McRae & W. Australia & DC & $\mathrm{b}, \mathrm{e}$ \\
\hline ABDP-9 178.60 & $2510-2500$ & Mt. McRae & W. Australia & DC & $b, e$ \\
\hline ABDP-9 147.30 & $2510-2500$ & Mt. McRae & W. Australia & DC & $b, e$ \\
\hline ABDP-9 174.67 & $2510-2500$ & Mt. McRae & W. Australia & DC & $b, e$ \\
\hline A82/5-97 & 1636 & Lynnot & N. Australia & DC & $\mathrm{a}$ \\
\hline MANTAI-277 & 1636 & Barney Creek & N. Australia & DC & $\mathrm{a}$ \\
\hline A82/2-473 & 1609 & Dungaminnie & N. Australia & DC & $c, e$ \\
\hline A82/3-512 & 1492 & Mainoru & N. Australia & DC & $\mathrm{c}, \mathrm{e}$ \\
\hline A82/3-328 & 1492-са 1400 & Crawford & N. Australia & DC & $\mathrm{c}, \mathrm{e}$ \\
\hline U5-412 & 1492-ca 1400 & Jalboi & N. Australia & DC & $c, e$ \\
\hline U5-130 & 1492-ca 1400 & Jalboi & N. Australia & DC & $\mathrm{c}, \mathrm{e}$ \\
\hline GG1-266 & 1492-ca 1400 & Corcoran & N. Australia & DC & $\mathrm{c}, \mathrm{e}$ \\
\hline BR1-229 & 1492 & Mainoru & N. Australia & DC & $\mathrm{c}, \mathrm{e}$ \\
\hline RS-4 & 1492-са 1400 & Velkerri & N. Australia & DC & $\mathrm{c}, \mathrm{e}$ \\
\hline RS-22 & 1492-ca 1400 & Velkerri & N. Australia & DC & $\mathrm{c}, \mathrm{e}$ \\
\hline RS-18 & 1492-са 1400 & Velkerri & N. Australia & DC & $\mathrm{c}, \mathrm{e}$ \\
\hline RS-13 & 1492-ca 1400 & Velkerri & N. Australia & DC & $\mathrm{c}, \mathrm{e}$ \\
\hline RS-21 & 1492-ca 1400 & Velkerri & N. Australia & DC & $\mathrm{c}, \mathrm{e}$ \\
\hline AK10-60-6 & ca $800-740$ & Kwagunt & N. America & OC & $\mathrm{c}, \mathrm{e}$ \\
\hline AK10-60-21 & ca $800-740$ & Kwagunt & N. America & OC & $\mathrm{c}, \mathrm{e}$ \\
\hline SP12 698 & ca $800-740$ & Galeros & N. America & $\mathrm{OC}$ & $c, e$ \\
\hline SP12 6322 & ca $800-740$ & Galeros & N. America & OC & $\mathrm{c}, \mathrm{e}$ \\
\hline SP12 694 & ca $800-740$ & Galeros & N. America & $\mathrm{OC}$ & $\mathrm{c}, \mathrm{e}$ \\
\hline SP12 534 & ca $800-740$ & Galeros & N. America & OC & $\mathrm{c}, \mathrm{e}$ \\
\hline SP14 6312 & ca $800-740$ & Galeros & N. America & OC & $\mathrm{c}, \mathrm{e}$ \\
\hline SP14 5317 & ca $800-740$ & Kwagunt & N. America & OC & $c, e$ \\
\hline SP12 634 & ca $800-740$ & Galeros & N. America & OC & $\mathrm{c}, \mathrm{e}$ \\
\hline SP12 537 & ca $800-740$ & Galeros & N. America & OC & $c, e$ \\
\hline SP14 5315 & ca $800-740$ & Kwagunt & N. America & OC & $\mathrm{c}, \mathrm{e}$ \\
\hline 402358 & ca $600-560$ & Vychegda & Russia & DC & $f$ \\
\hline 462398 & ca $600-560$ & Vychegda & Russia & DC & $f$ \\
\hline 552504 & ca $600-560$ & Vychegda & Russia & DC & $f$ \\
\hline 612606 & ca $600-560$ & Vychegda & Russia & DC & $f$ \\
\hline 742688 & ca $600-560$ & Vychegda & Russia & DC & $f$ \\
\hline 832779 & ca $600-560$ & Vychegda & Russia & DC & $f$ \\
\hline 942821 & ca $600-560$ & Vychegda & Russia & DC & $f$ \\
\hline TO-320 & 635-ca580 & Dracoisen & Svalbard & OC & $\mathrm{c}, \mathrm{e}$ \\
\hline OMR 010 & $<600-550$ & Shuram & Oman & DC & $a$ \\
\hline PIN-5079/61 & ca 550 & Redkino & Russia & OC & $\mathrm{c}, \mathrm{e}$ \\
\hline K05-M-4 & ca 550 & Redkino & Russia & OC & $\mathrm{c}, \mathrm{e}$ \\
\hline TSES-4275 & $549-545$ & Schwarzrand & Namibia & DC & $a$ \\
\hline TSES-5150 & $549-545$ & Nudaus & Namibia & DC & a \\
\hline OMR 002 & $550-547$ & Buah & Oman & DC & a \\
\hline OMR 017 & $550-547$ & Buah & Oman & DC & $\mathrm{a}$ \\
\hline
\end{tabular}




\begin{tabular}{cccccc} 
OMR 003 & 541 & Thuleilat shale & Oman & DC & a \\
OMR 021 & 541 & Thuleilat shale & Oman & DC & a \\
OMR 022 & 541 & Thuleilat shale & Oman & DC & a \\
$96-$ Ko-41 & ca $545-543$ & Kotlin & Estonia & OC & c, e \\
$96-$ Ko-31 & ca $545-543$ & Kotlin & Estonia & OC & c, e \\
HU-61483 & ca $540-530$ & Tokammane & Svalbard & OC & c, e \\
AE-1845 & ca 540-530 & Tokammane & Svalbard & OC & c,e \\
\hline
\end{tabular}

666 a. Below greenschist facies equivalent $\left(<200^{\circ} \mathrm{C}\right.$ max.); b. Prehnite-pumpellyite facies equivalent

667 to $<300^{\circ} \mathrm{C}$; c. Burial diagenesis to $\sim 75^{\circ} \mathrm{C}$; d. Fabric retentive diagenetic dolomite; e. Minimum

668 deformation fabric; f. Burial diagenesis to $120-150^{\circ} \mathrm{C}$ max; OC: outcrop sample; DC: drillcore 669 sample.

670

671

672

673 Table 2: Mineralogical and geochemical characteristics of samples discussed in this study. All

674 mineral abundances and TOC are in wt. \%. TOC: total organic carbon, SR: Schultz ratio, CIA:

675 chemical index of alteration (see text). 


\begin{tabular}{|c|c|c|c|c|c|c|c|c|c|c|c|c|c|c|c|}
\hline Sample & TOC & $S R$ & $\begin{array}{c}\text { paleo } \\
\text { CIA }\end{array}$ & $\begin{array}{c}C I A \\
\text { (Meso. } \\
\text { UC)* }\end{array}$ & Qtz & Kspar & Plag & Glauc. & $2 M 1$ & $1 M$ & $1 M d$ & Chlorite & Kaol. & Smect. & Source ${ }^{* *}$ \\
\hline GKPO1 248.09 & 8.4 & 0.20 & 82.1 & -- & 19.5 & 34.8 & 0.0 & 0.0 & 11.5 & 0.0 & 0.0 & 16.3 & 0.0 & 0.0 & L. Archean UC \\
\hline GKPO1 483.90 & 6.6 & 2.43 & 68.6 & -- & 7.1 & 0.0 & 0.0 & 0.0 & 24.1 & 7.1 & 0.0 & 0.0 & 0.0 & 0.0 & L. Archean UC \\
\hline GKPO1 385 & 1.11 & 1.93 & 81.4 & -- & 0.0 & 18.4 & 0.0 & 9.7 & 38.1 & 19.7 & 11.6 & 5.6 & 0.0 & 0.0 & L. Archean UC \\
\hline GKPO1 1017 & 2.67 & 1.22 & 84.1 & -- & 19.1 & 0.0 & 0.0 & 0.0 & 33.0 & 32.5 & 0.0 & 12.1 & 0.0 & 0.0 & L. Archean UC \\
\hline ABDP-9 149.30 & 12.09 & 0.21 & 85.4 & -- & 17.7 & 40.0 & 0.0 & 7.8 & 14.4 & 6.8 & 0.0 & 6.5 & 0.0 & 0.0 & L. Archean UC \\
\hline ABDP-9 178.60 & 4.87 & 0.07 & 85.4 & -- & 26.1 & 36.9 & 0.9 & 0.0 & 8.3 & 3.6 & 0.0 & 14.0 & 0.0 & 0.0 & L. Archean UC \\
\hline ABDP-9 147.30 & 12.6 & 0.13 & 86.1 & -- & 32.4 & 31.5 & 0.0 & 5.4 & 6.6 & 7.6 & 0.0 & 10.8 & 0.3 & 0.0 & L. Archean UC \\
\hline ABDP-9 174.67 & 2.92 & 0.02 & 85.1 & -- & 25.4 & 28.8 & 0.0 & 0.0 & 2.5 & 0.0 & 0.0 & 19.8 & 0.0 & 0.0 & L. Archean UC \\
\hline A82/5-97 & 4.5 & 0.10 & 83.0 & -- & 30.8 & 26.9 & 0.0 & 14.8 & 4.0 & 0.0 & 0.0 & 4.7 & 0.0 & 0.0 & L. Archean UC \\
\hline MANTAI-277 & 3.9 & 0.33 & 85.3 & -- & 32.2 & 14.2 & 0.0 & 16.6 & 19.1 & 3.6 & 3.6 & 7.1 & 1.2 & 0.0 & L. Archean UC \\
\hline A82/2-473 & 2.45 & 0.43 & 83.8 & -- & 21.3 & 0.0 & 0.0 & 12.8 & 40.6 & 12.0 & 4.5 & 7.3 & 0.0 & 0.0 & L. Archean UC \\
\hline A82/3-512 & 2.1 & 0.09 & 74.6 & -- & 47.4 & 3.8 & 5.6 & 5.7 & 17.3 & 2.9 & 0.0 & 10.3 & 0.0 & 0.0 & L. Archean UC \\
\hline A82/3-328 & 3.1 & 0.33 & 83.8 & -- & 18.2 & 3.7 & 0.0 & 15.8 & 36.2 & 15.5 & 5.7 & 6.4 & 0.0 & 0.0 & L. Archean UC \\
\hline U5-412 & 2.5 & 0.27 & 81.9 & -- & 41.2 & 6.5 & 0.0 & 16.4 & 15.6 & 0.0 & 0.0 & 17.6 & 0.0 & 0.0 & L. Archean UC \\
\hline U5-130 & 1.5 & 0.12 & 81.3 & -- & 66.0 & 0.0 & 0.1 & 5.8 & 14.5 & 11.8 & 3.6 & 0.8 & 0.0 & 0.0 & L. Archean UC \\
\hline GG1-266 & 3.3 & 0.82 & 83.5 & -- & 28.4 & 0.0 & 0.0 & 13.6 & 46.7 & 0.0 & 0.0 & 8.0 & 0.0 & 0.0 & L. Archean UC \\
\hline BR1-229 & 2.5 & 0.04 & 78.4 & -- & 62.4 & 8.1 & 2.6 & 0.0 & 15.1 & 0.0 & 0.0 & 6.5 & 0.0 & 0.0 & L. Archean UC \\
\hline RS-4 & 12.4 & 0.14 & 72.0 & -- & 53.1 & 2.1 & 3.9 & 14.1 & 8.7 & 13.4 & 6.4 & 2.4 & 0.0 & 0.0 & L. Archean UC \\
\hline RS-22 & 12.6 & 0.24 & 74.7 & -- & 45.9 & 4.8 & 2.4 & 14.0 & 10.1 & 10.7 & 6.8 & 1.4 & 0.0 & 0.0 & L. Archean UC \\
\hline RS-18 & 11.3 & 0.20 & 70.7 & -- & 43.0 & 3.8 & 4.8 & 19.8 & 5.6 & 14.5 & 6.3 & 3.7 & 0.0 & 0.0 & L. Archean UC \\
\hline RS-13 & 7 & 0.21 & 73.6 & -- & 56.1 & 0.7 & 2.9 & 8.6 & 12.1 & 15.0 & 10.9 & 2.4 & 0.0 & 0.0 & L. Archean UC \\
\hline RS-21 & 5.7 & 0.24 & 78.2 & -- & 47.2 & 5.3 & 1.8 & 11.9 & 9.3 & 19.2 & 9.4 & 2.4 & 0.0 & 0.0 & L. Archean UC \\
\hline AK10-60-6 & 6.6 & 0.55 & 81.9 & 85.9 & 29.2 & 0.0 & 0.0 & 2.7 & 35.4 & 0.0 & 0.0 & 2.4 & 27.0 & 0.0 & Granitic \\
\hline AK10-60-21 & 8.9 & 0.34 & 78.7 & 82.4 & 34.7 & 0.9 & 0.0 & 15.5 & 18.1 & 19.1 & 11.7 & 0.5 & 5.0 & 0.0 & Granitic \\
\hline SP12 698 & 4.68 & 0.62 & 79.7 & 83.7 & 26.2 & 0.0 & 0.0 & 4.2 & 22.3 & 15.7 & 15.6 & 1.0 & 11.5 & 0.0 & Granitic \\
\hline SP12 6322 & 3.89 & 0.18 & 81.4 & 85.4 & 37.1 & 1.6 & 0.1 & 1.5 & 18.4 & 17.4 & 0.0 & 0.1 & 19.4 & 0.0 & Granitic \\
\hline SP12 694 & 0.31 & 1.33 & 77.3 & 81.1 & 21.6 & 0.0 & 0.0 & 10.3 & 29.6 & 28.3 & 1.5 & 0.9 & 1.4 & 0.0 & Granitic \\
\hline SP12 534 & 4.92 & 0.05 & 58.3 & 61.4 & 65.8 & 8.5 & 11.1 & 0.8 & 5.9 & 1.1 & 0.0 & 3.3 & 0.0 & 0.0 & Granitic \\
\hline SP14 6312 & 0.08 & 0.27 & 80.3 & 84.1 & 59.9 & 0.0 & 0.0 & 1.2 & 18.2 & 9.4 & 0.1 & 1.0 & 7.6 & 0.0 & Granitic \\
\hline SP14 5317 & 4.91 & 0.52 & 80.9 & 84.9 & 29.3 & 0.4 & 0.0 & 11.8 & 20.8 & 5.8 & 6.1 & 2.0 & 18.8 & 0.9 & Granitic \\
\hline SP12 634 & 4.96 & 0.20 & 75.1 & 78.8 & 55.5 & 0.6 & 3.2 & 1.7 & 12.0 & 7.5 & 1.0 & 0.4 & 14.0 & 1.8 & Granitic \\
\hline SP12 537 & 4.97 & 0.17 & 76.4 & 79.1 & 24.4 & 1.2 & 1.6 & 0.8 & 6.7 & 0.0 & 0.0 & 8.4 & 0.7 & 8.2 & Granitic \\
\hline
\end{tabular}




\begin{tabular}{|c|c|c|c|c|c|c|c|c|c|c|c|c|c|c|c|}
\hline 402358 & 2.37 & 0.45 & 59.0 & 60.9 & 29.4 & 2.5 & 21.3 & 11.5 & 12.1 & 3.4 & 2.3 & 11.6 & 0.8 & 0.0 & Granitic \\
\hline 462398 & 4.62 & 0.71 & 58.5 & 59.2 & 13.4 & 2.7 & 38.7 & 6.8 & 10.1 & 4.6 & 0.0 & 16.6 & 0.0 & 0.0 & Granitic \\
\hline 552504 & 2.57 & 0.12 & 61.4 & 67.8 & 48.4 & 5.8 & 8.6 & 4.4 & 15.1 & 1.7 & 5.1 & 1.0 & 2.2 & 0.0 & Granitic \\
\hline 612606 & 5.03 & 0.55 & 62.7 & 69.2 & 28.7 & 1.4 & 10.3 & 14.6 & 21.7 & 2.8 & 0.0 & 6.8 & 1.7 & 1.2 & Granitic \\
\hline 742688 & 4.14 & 0.23 & 61.0 & 67.3 & 37.1 & 4.1 & 10.9 & 14.1 & 16.0 & 1.3 & 0.0 & 7.3 & 0.0 & 0.0 & Granitic \\
\hline 832779 & 2.59 & 0.38 & 58.5 & 64.3 & 32.3 & 8.1 & 15.0 & 5.0 & 20.9 & 4.4 & 0.0 & 4.1 & 0.0 & 0.0 & Granitic \\
\hline 942821 & 2.7 & 0.11 & 66.8 & 73.2 & 65.5 & 6.4 & 3.7 & 4.5 & 6.8 & 3.0 & 0.0 & 5.7 & 0.0 & 0.0 & Granitic \\
\hline TO 320 & 5.8 & 0.38 & 84.9 & 85.1 & 15.2 & 18.1 & 0.0 & 12.6 & 26.9 & 0.2 & 0.2 & 2.5 & 17.2 & 0.0 & Neoprot. UC \\
\hline K05-M-4 & 3.1 & 0.65 & 55.8 & 63.3 & 18.8 & 0.0 & 13.1 & 16.3 & 36.6 & 0.0 & 0.0 & 7.0 & 0.0 & 0.0 & Charnockitic \\
\hline PIN 5079/61 & 3.4 & 0.43 & 60.9 & 68.9 & 22.2 & 3.2 & 9.5 & 22.7 & 22.9 & 1.7 & 0.6 & 10.5 & 0.4 & 0.0 & Charnockitic \\
\hline 96-Ко-41 & 2.9 & 0.26 & 59.0 & 83.2 & 35.0 & 11.2 & 0.0 & 0.5 & 36.0 & 0.0 & 0.0 & 4.5 & 1.0 & 0.0 & Potassic granite \\
\hline 96-Кo-31 & 2.9 & 0.23 & 58.9 & 83.5 & 38.6 & 13.2 & 0.0 & 8.4 & 23.2 & 2.2 & 2.2 & 5.0 & 1.3 & 0.0 & Potassic granite \\
\hline 95-Кo-4E & 3.45 & 0.44 & 58.7 & 84.0 & 32.2 & 12.6 & 0.0 & 11.2 & 27.1 & 2.6 & 0.0 & 4.0 & 6.5 & 0.0 & Potassic granite \\
\hline TSES 4275 & 3.1 & 1.10 & 55.9 & 72.4 & 16.7 & 0.0 & 6.2 & 0.0 & 59.0 & 0.0 & 0.0 & 9.1 & 0.0 & 0.0 & Charnockitic \\
\hline TSES 5150 & 3.5 & 0.73 & 62.7 & 81.6 & 24.5 & 0.0 & 0.4 & 7.0 & 47.0 & 2.7 & 0.0 & 10.5 & 0.0 & 0.0 & Charnockitic \\
\hline OMR 003 & 8 & 0.20 & 79.0 & 87.5 & 46.0 & 3.2 & 0.0 & 0.0 & 7.0 & 4.2 & 0.0 & 0.0 & 4.1 & 1.0 & Granitic \\
\hline OMR 021 & 6.4 & 0.19 & 75.0 & 80.3 & 59.4 & 2.0 & 1.0 & 0.0 & 6.4 & 1.7 & 0.0 & 0.0 & 6.6 & 0.0 & Granitic \\
\hline OMR 022 & 2.5 & 0.34 & 74.0 & 82.4 & 23.1 & 3.5 & 1.3 & 0.0 & 4.8 & 8.6 & 0.1 & 0.9 & 3.5 & 0.0 & Granitic \\
\hline OMR 002 & 1.6 & 0.18 & 49.5 & 54.9 & 47.7 & 5.3 & 13.0 & 2.4 & 9.5 & 4.4 & 1.6 & 0.3 & 0.0 & 0.0 & Granitic \\
\hline OMR 017 & 2.3 & 0.11 & 50.0 & 55.8 & 55.3 & 4.7 & 7.9 & 1.6 & 3.5 & 6.1 & 0.0 & 0.0 & 1.4 & 0.0 & Granitic \\
\hline OMR 010 & 2.5 & 0.22 & 64.4 & 71.5 & 38.2 & 1.3 & 4.6 & 0.3 & 9.6 & 3.3 & 0.2 & 1.8 & 1.3 & 0.0 & Granitic \\
\hline HU 61483 & 3 & 0.41 & 55.7 & 83.5 & 4.0 & 48.4 & 0.0 & 2.8 & 29.9 & 0.0 & 0.0 & 2.8 & 3.7 & 0.0 & Granite? \\
\hline AE 1845 & 5.5 & 0.27 & 72.0 & 72.8 & 25.5 & 8.4 & 4.8 & 1.7 & 35.7 & 0.0 & 0.0 & 4.3 & 0.0 & 0 & Granite? \\
\hline
\end{tabular}

*Paleo-CIA values recalculated in reference to average upper crust at the Mesoproterozoic/Neoproterozoic transition. Although for most samples the source composition can be constrained, average upper crust represents a low-K source and, in cases where few constraints on the source composition exist, serves to estimate “maximum” paleo-CIA values.

**Source composition used to estimate paleo-CIA values listed in the “paleo-CIA” column and shown in Figure 6. 


\section{Figure Captions:}

Figure 1: Proportion of $2 M_{1}$ illite (including muscovite) in the clay fraction in Proterozoic samples. Averages for each basin indicate that $2 M_{1}$ mica-illite dominates the clay mineralogy in across Neoproterozoic samples.

Figure 2: Proportion of $1 M / 1 M_{\mathrm{d}}$ illite and glauconite in the clay fraction in Proterozoic samples. Averages for each basin indicate that these phases are minor components in Neoproterozoic samples.

Figure 3: A-CN-K molar ternary diagram with mineral compositions plotted for reference. Unweathered source rock compositions lie along the plagioclase-K-feldspar join, with mafic compositions plotting toward the A-CN join, and more potassic compositions plotting toward the A-K join. Chemical weathering of a given unaltered source rock composition is indicated by the blue line. K-metasomatism in the form of K-addition to aluminous clay minerals is indicated by the red line. K-substitution in plagioclase is indicated by the green line. Correction for Kmetasomatism allows estimates of pre-metamorphosed CIA values (shown on left hand vertical axis). Mineralogical and/or petrographic information is required to infer whether samples have become weathered and subsequently enriched in $\mathrm{K}$, or whether simple K-substitution in feldspar is responsible for its position on this diagram.

Figure 4: A-CN-K molar ternary diagram plotting late Archean and Mesoproterozoic samples analyzed in this study. All samples plot on an array extending from a region of the A-CN join consistent with smectite-kaolinite mixing. Relative to average upper Archean upper crust, all 
samples have been significantly affected by K-metasomatism upon diagenesis and metamorphism. Circles: Late Archean; triangles (down): Lynnot, Barney Creek and Dungaminnie Fmn.; squares: Mainoru, Crawford, Jalboi, Corcoran, Velkerri Fmn.

Figure 5: A-CN-K molar ternary diagram plotting Neoproterozoic samples analyzed in this study. These samples reflect various degrees of feldspar weathering, source compositions and Kmetasomatism. All samples are enriched in $\mathrm{K}_{2} \mathrm{O}$ relative to average upper crust at the Mesoproterozoic/Neoproterozoic transition, but in most cases source compositions are constrained by best fits to sample suites combined with mineralogical analyses. Filled circles: Kwagunt and Galeros Fmn.; triangles (down): Vychegda Fmn.; squares: Dracoisen Fmn.; diamonds: Redkino, Schwarzrand and Nudaus Fmn.; triangles (up): Kotlin Fmn.; empty circles: Shuram, Buah, Thuleilat Fmn.; hexagons: Tokammane Fmn.

Figure 6: Estimated paleo-CIA values for each sample derived from constraints on source composition (discussed in text) and correction for K-metasomatism. Late Archean through Mesoproterozoic samples reflect moderate to intense weathering. Neoproterozoic samples generally exhibit lower paleo-CIA values, which are controlled by the contribution of immature (relatively unweathered) sediment. Values from Condie et al. (2001) represent formation averages.

Figure 7: Total organic carbon (in wt. \%) as a function of estimated paleo-CIA value. The highest TOC samples occur at CIA values which correspond to weathering conditions most conducive to smectite genesis (shaded field). The majority of more intensely weathered samples 
exhibit lower TOC values under conditions where smectites become destabilized by intense leaching. Grey circles: Late Archean; empty triangles (down): Lynnot, Barney Creek and Dungaminnie Fmn.; empty squares: Mainoru, Crawford, Jalboi, Corcoran, Velkerri Fmn.; filled circles: Kwagunt and Galeros Fmn.; filled triangles (down): Vychegda Fmn.; filled squares: Dracoisen Fmn.; diamonds: Redkino, Schwarzrand and Nudaus Fmn.; triangles (up): Kotlin Fmn.; empty circles: Shuram, Buah, Thuleilat Fmn.; hexagons: Tokammane Fmn.

Figure 8: Total organic carbon (in wt. \%) as a function of "illite crystallinity”, expressed by the full width at half maximum of the $10 \AA$ illite 001 peak. A larger FWHM corresponds to finer crystallite size. The $10 \AA$ peak represents the contribution of $2 M_{1}, 1 M$ and $1 M_{\mathrm{d}}$ illite and glauconite present in the sample. The highest TOC samples are associated with the finest illite crystallite size, which is likely the product of physical aggregation and the interference of OM with the illitization reaction. This potential interference preserves illite polytype and crystal size, but could lead to the association of high surface area with high TOC content observed in ancient siliciclastic rocks. Grey circles: Late Archean; triangles (down): Lynnot, Barney Creek and Dungaminnie Fmn.; squares: Mainoru, Crawford, Jalboi, Corcoran, Velkerri Fmn.; filled circles: Kwagunt and Galeros Fmn.; diamonds: Redkino, Schwarzrand and Nudaus Fmn.; triangles (up): Kotlin Fmn.

Figure 9: Schultz ratio measured in Proterozoic samples. The Schultz ratio is an empirical measurement of the relative peak intensities between all phyllosilicates (including all illite polytypes, chlorite, muscovite and weathering-derived clays) and quartz. Schultz ratios are variable across all samples, with Neoproterozoic samples exhibiting, on average, higher values 
than more ancient samples. However, the contribution of later generations of quartz cement cannot be distinguished with XRD data alone.

Figure 10: Schultz ratio as a function of $2 M_{1}$ illite (including muscovite) content (in wt. \%). The strong correlation shows that Schultz ratios in our samples are strongly controlled by igneous/detrital clays, with Neoproterozoic samples exhibiting the highest values. Late Archean samples that contain appreciable chlorite exhibit some of the highest Schultz ratios measured. 